\title{
Twinning in Cattle: A Review
}

\author{
Rajesh Wakchaure $^{1} \&$ Subha Ganguly ${ }^{2 *}$ \\ ${ }^{1}$ Associate Professor, Department of Animal Genetics \& Breeding, \\ ${ }^{2}$ Associate Professor, Department of Veterinary Microbiology, ARAWALI VETERINARY \\ COLLEGE (Affiliated with Rajasthan University of Veterinary and Animal Sciences, Bikaner), \\ N.H. - 52 Jaipur Road, V.P.O. Bajor, Sikar - 332001, Rajasthan, India \\ ganguly38@gmail.com
}

\begin{abstract}
The occurrence of twinning may have both positive and negative effects. Twinning is associated not only with increased dystocia, increased incidence of retained placenta, greater rate of abortion and post partum interval, higher culling rate in cow but also mortality in twin calves. Twinning is helpful for obtaining more progeny from a genetically superior female and can considerably increase the efficiency of production in cattle.
\end{abstract}

Keywords: Twinning, dystocia, parity

\section{INTRODUCTION}

Twinning a highly desirable trait, this indicates an increased reproductive capacity of an animal. However, in a uniparous species, like a cow, multiple births occur rarely. Twinning rate in cattle controlled either through genetic selection ${ }^{1}$, hormonal treatments ${ }^{2}$, embryo transfer $^{3}$ and hormones ${ }^{4}$. In general, twinning rate was found to be mostly higher in breeds of dairy cattle than beef cattle. Small sized cattle breeds are likely to have twins at lower frequency. Part of the variation in twinning rate must also be due to some environmental factors including parity, age of the dam and season of the year. ${ }^{5}$ Twinning occurs relatively rarely, with the frequency generally not exceeding $1 \%$ in most beef herds and on average 3 to $5 \%$ in dairy herds and is strongly affected by age and parity of the dam. ${ }^{6}$ Twinning rate is also slightly influenced by seasonal effects, more multiple births during the spring ${ }^{7}$ or autumn months ${ }^{8}$. The largest increase in twinning rate is between first calving and second calving. Parity of the dam is clearly associated with an increase in twinning rate. In high producing dairy cattle there was an increase from a twinning rate of about $1 \%$ in heifers to 6 to $7 \%$ in second parity cows. ${ }^{9} \mathrm{~A}$ direct relationship between high milk production and the increased incidence of double ovulation, which may subsequently result in increased twinning. ${ }^{10}$ The value of heritability was estimated to range from less than 0.01 to $0.09 .{ }^{11}$ Ovulation rate closely related to twinning, when considered as a single observation, also has a low heritability of $0.07-0.11 .{ }^{12}$ However, when multiple oestrous cycles are taken into consideration, heritability is considerably higher. The genetic correlation between twinning and ovulation rates ranges from 0.75 to $1.0 .{ }^{13}$ Thus, twinning rate in cattle is likely to be inherited as a typical quantitative trait, controlled by the combined action of many genes modified by environmental factors. Twinning in cattle is stimulated by treatment with exogenous gonadotrophin when dairy cattle were given a single injection of pregnant mare's serum gonadotrophin (PMSG) during the follicular phase of the cycle.

\section{TYPES OF TWIN}

Bovine twins are of the two types 1) Monozygotic twins are genetically and physically identical, since they are formed from one fertilized egg, which splits into two identical halves during early embryonic developmental stages. Thereby both individuals are always the same sex. 2) Dizygotic or fraternal twins are not identical genetically or phenotypically as monozygotic twins, since they are formed from two different sperm fertilize with two completely different ova at the same time. Thus, the successful result of ovulation and fertilization of two oocytes will be dizygotic twins. Dizygotic twins are not necessarily the same sex. They can be also as similar or different as any two siblings born from the same parents during different gestations. 


\section{Advantages OF TWINNING}

Twinning provides a chance to improve the efficiency of beef production for producers. Increased frequency of twinning would increase the potential for obtaining more progeny from a genetically superior female, thereby allowing those females to play a larger role in a selection program. ${ }^{14}$ Twin births offer the potential for increased beef production efficiency. ${ }^{15}$ Cows with twins produce more milk, fat and protein than cows with single calves at every parity group. ${ }^{16}$

\section{Disadvantages of Twinning}

In dairy cattle, twin births have generally considered as detrimental due to increased problems in the dam and calf leading to increased costs. Twinning is associated with increased incidence of retained placenta, higher mortality rates, frequent occurrence of freemartins and longer interval from parturition to first estrous ${ }^{17}$, lower potential of calf survival, increased culling rate and poor reproductive performance. ${ }^{18}$ A 12 day longer interval from parturition to the next conception for cows occurs after giving birth to twins as compared to cows that carried only one calf. ${ }^{19}$ The incidence of retention of placental membranes is increased after a twin birth ${ }^{20}$ and is also increased after a twin birth with dystocia. ${ }^{21}$ A study conducted in Egypt, a culling rate was reported $61.53 \%$ for twin calving cows versus $30.73 \%$ for single bearing. ${ }^{22}$ A study conducted on beef cattle experimental herds in Canada observed reduced gestation lengths. ${ }^{23}$ Abortion also occurs more often during twin pregnancy. ${ }^{24}$ Cows with twins have lower milk production. ${ }^{7}$

\section{Controlling Problems in TwinNing}

The problems occurred in twinning can be avoided by the measures like pre calving diagnosis of twin pregnancies, appropriate nutrition, suitable calving facilities and early weaning of twin calves.

\section{CONClusion}

Successful use of twinning in cattle production, will require nutrition and generally improved management for twin producing cows to overcome problems, which including a higher risk of dystocia, retained placenta, metritis, abortion, calf mortality, poor postpartum reproduction, increased culling rate and freemartin heifers. The increase in twinning rate, despite low heritability of this trait, can be achieved through selection, when multiple observations of ovulation rate are used as the indirect selection criterion.

\section{REFERENCES}

[1] Van Tassell CP, Van Vleck LD, Gregory KE. Bayesian analysis of twinning and ovulation rates using a multiple-trait threshold model and Gibbs sampling. J. Anim Sci 1998:76: 2048-2061.

[2] McCaughe WJ, Dow C. Hormonal induction of twinning in cattle. Vet Rec 1977; 100: 29-30.

[3] Sreenan JM, Diskin.G. Effect of a unilateral or bilateral twin embryo distribution on twinning and embryo survival rate in the cow. J Reprod Fertil 1989; 87: 657-664.

[4] Morris DG, McDermott MG, Diskin MG, Morrison CA, Swift PJ, Sreenan JM. Effect of immunization against synthetic peptide sequences of bovine inhibin alpha-subunit on ovulation rate and twin-calving rate in heifers. J Reprod Fertil 1993; 97:255-261.

[5] Rutledge JJ. Twinning in cattle. J Anim Sci 1975; 40: 803-815.

[6] Ghavi Hossein-Zadeh N, Nejati-Javaremi A, Miraei-Ashtiani SR, Kohram H. Estimation of variance components and genetic trends for twinning rate in Holstein dairy cattle of Iran. J Dairy Sci 2009; 92: 3411-3421.

[7] Chaplin CA, Van Vleck LD. Effects of twinning on lactation and days open in Holsteins. J Dairy Sci 1980; 63: 1881-1886.

[8] Gregory KE, Bennett GL, Van vleck LD, Echternkamp SE, Cundiff LV. Genetic and environmental parameters for ovulation rate, twinning rate, and weight traits in a cattle population selected for twinning. J Anim Sci 1997; 75: 1213-1222.

[9] Berry SL, Ahmadi A, Thurmond MC. Periparturient disease on large, dry lot dairies: interrelationships of lactation, dystocia, calf number, calf mortality, and calf sex. J Dairy Sci 1994; 77(Suppl. 1):379. (Abstr.). 
[10] Wiltbank MC, Fricke PM, Songsritavong S, Sartoi R, Ginther OJ. Mechanisms that prevent and produce double ovulations in dairy cattle. J Dairy Sci 2000; 83: 2998-3007.

[11] Cady RA, Van Vleck LD. Factors affecting twinning and effects of twinning in Holstein dairy cattle. J Anim Sci 1978; 46(4): 950-956.

[12] Gregory KE, Echternkamp SE, Dickerson GE, Cundiff LV, Hoch RM, Van vleck LD. Twinning in cattle: I. Foundation animals and genetic and environmental effects on twinning rate. J Anim Sci 1990; 68: 1867-1876.

[13] Van vleck LD, Gregory KE, Echternkamp SE. Ovulation rate and twinning rate in cattle: heritabilities and genetic correlation. J Anim Sci 1991; 69: 3213-3219.

[14] Karlsen A, Ruane J, Klemetsdal G, Heringstad B. Twinning rate in Norwegian cattle: Frequency, (co)variance components, and genetic trends. J Anim Sci 2000; 78: 15-20.

[15] Kirkpatrick BW. Management of twinning cow herds. J Anim Sci 2002; 80(E. Suppl 2): E14E18.

[16] Wood PDP. Some attributes of twin-bearing British Friesian and Canadian Holstein cows recorded in England and Wales. J Dairy Res 1984; 51: 365-370.

[17] Echternkamp SE, KE Gregory. Reproductive, growth, feedlot, and carcass traits of twin vs single births in cattle. J Anim Sci 2002; 80(E. Suppl. 2): E64-E73.

[18] Andreu-Vázquez C, García-Ispierto I, Ganau S, Fricke PM, López-Gatius F. Effects of twinning on the subsequent reproductive performance and productive lifespan of high-producing dairy cows. Theriogenology 2012; 78: 2061-2070.

[19] Echternkamp SE, Gregory KE. Effects of twinning on postpartum reproductive performance in cattle selected for twin births. J Anim Sci 1999; 77: 48-60.

[20] Bellows RA, Short RE, Urick JJ, Pahnish OF. Effects of early weaning on postpartum reproduction of the dam and growth of calves born as multiples or singles. J Anim Sci 1974; 39: 589-600.

[21] Echternkamp SE, Thallman RM, Cushman RA, Allan MF, Gregory KE. Increased calf production in cattle selected for twin ovulations. J Anim Sci 2007; 85: 3239-3248.

[22] Mostafa AS. Effect of twin vs. single births on gestation length, reproductive performance, dystocia, calf survival rate and culling in Holstein cows. Bs. Vet Med. J 2009; 19 (2):19-23.

[23] De Rose, EP and Wilton JW. Productivity and profitability of twin births in beef cattle. J Anim Sci 1991; 69: 3085-3093.

[24] Hossein-Zadeh NG, Nejati-Javaremi A, Miraei-Ashtiani SR, Kohram H. An observational analysis of twin birds, calf stillbirths, Calf sex ratio, and abortion in Iranian Holsteins. J Dairy Sci 2008; 91: 4198-4205. 